https://doi.org/10.18485/bogoljub_stankovic.2018.ch1

811.16:061.6(497.11)"1948/2018"

\author{
ПЕТАР БУњАК* \\ Универзитет у Београду \\ Филолошки факултет \\ Катедра за славистику
}

\title{
ОСНИВАњЕ СЛАВИСТИЧКОГ ДРУШТВА СРБИЈЕ ПРЕМА ТЗВ. „НОВОМ СЛОВЕНСКОМ ПОКРЕТУ”
}

\begin{abstract}
Оснивање Славистичког друштва Србије 29. јуна 1948. посматра се у контексту „новог словенског покрета” као идеолошко-пропагандног оружја СКП (б) у борби с фашизмом за време и после II светског рата. Указује се на неподударност модела славистике који је промовисао „нови словенски покрет” и доминантно филолошког модела који су заступали оснивачи Славистичког друштва Србије. Такође се супротставља академско поимање славистике у прошлости и садашњости тзв. „параславистици”.
\end{abstract}

Кључне речи: „нови славистички покрет”, идеологија комунизма, славистика, „параславистика", Славистичко друштво Србије

Petar Bunjak

\section{FOUNDING OF THE SERBIAN ASSOCIATION FOR SLAVIC STUDIES VS. THE SO-CALLED "NEW SLAVIC MOVEMENT"}

The founding of the Serbian Association for Slavic Studies that took place on June 29,1948 is fitted into the context of the "new Slavic movement" as the ideological propaganda weapon of the All-Union Communist Party (bolsheviks) in its struggle against fascism during the World War Two, which was widely supported by the post-war "people's democracy" regimes in Slavic countries. The author points to the incompatibility of the model of Slavic studies that was promoted by the "new Slavic movement" and the predominantly philological model represented by the founders of the Serbian Association for Slavic Studies. The academic understanding of Slavic studies is opposed to the Slavic "para-studies" in the past and the present.

Keywords: the "new Slavic movement", Communist ideology, Slavic studies, Slavic "para-studies", Serbian Association for Slavic Studies

\footnotetext{
*p.bunjak@fil.bg.ac.rs
} 
У години када се у Београду и Србији одржава XVI међународни конгрес слависта струковно удружење српских слависта обележава седамдесет година свога постојања. Иронијом судбине, један од оних који су се снажно залагали да Београд добије организацију међународног славистичког конгреса, а уз то стуб-потпорањ Славистичког друштва Србије у његовој новијој историји и његов презаслужни историчар, професор Богољуб Станковић, није доживео да види свој остварени сан и своје друштво на прагу осме деценије трајања. О историјату Друштва од професора Богољуба Станковића, аутора књиге 60 їодина Славистиичкоі gрушишва Србије (2008), мериторније не би могао говорити нико од нас, његових некадашњих сарадника.

Због тога сам - одужујући притом један давнашњи дуг према проф. Станковићу (вид. Буњак 2012: 61-62) - одабрао да за ову прилику унеколико подсетим на контекст у којем је у лето 1948. Славистичко друштво основано, као и да покушам да отклоним неке предрасуде. Проф. Станковић и ја планирали смо, наиме, коауторско истраживање архивске грађе о Словенском комитету Југославије и уопште о стању наше славистике у првим годинама после II светског рата. Споменуто истраживање извора није обављено, али на основну релевантних историјских радова могуће је реконструисати макар основне обрисе појава и процеса.

Кад се писало о оснивању Славистичког друштва Србије досад се углавном пажљиво избегавала идеолошка димензија овога прегнућа наших великих претходника, а шира друштвена клима ретуширала се и редовно стављала у други план. Није то чињено случајно, нити из непознавања чињеница, већ како се не би бацала сенка на све оно што је Славистичко друштво већ при својим првим корацима уистину било, а поготово на оно што је током деценија постало. С друге стране, уврежило се мишљење да је Славистичко друштво основано само ради организовања учешћа на неодржаном свесловенском конгресу слависта у Москви 1948.

Основни је задатак овога прилога да отворено проговори о можда непријатним и деликатним питањима, али искључиво с циљем да се покаже како су споменуте бојазни неосноване, а наведено мишљење - заблуда.

При томе ће бити нешто више речи о ономе за шта се у нашим круговима не може рећи да је општепознато, док ће се чињенице из ране историје нашег друштва третирати као домен подразумеваног.

Пођимо, дакле, од једнога броја чињеница из друштвене и политичке историје које су претходиле великом дану за Славистичко друштво Србије - 29. јуну 1948. године, датуму његовог оснивања. 


\section{1. Шта је „нови словенски покрет”?}

За време II светског рата, као једно од значајних и прилично делотворних пропагандно-политичких оружја у борби с фашизмом, разрађена је у Совјетском Савезу идеја свесловенског антифашистичког покрета. Свесно је промовисана словенска узајамност и солидарност, словенско „борбено братство”, што је, како се ценило, знатно ефикасније будило патриотска осећања од идеолошке „линије” пролетерског интернационализма. С тим је циљем у августу 1941. године у Москви одржан први свесловенски митинг, ${ }^{1}$ на којем је основан Свесловенски комитет (Всеславянский комитет). Била је то друштвена организација најнепосредније подређена Централном комитету СКП(б) и Совинформбироу. Задатак у ратним и поратним годинама био му је одржавање везе с пробољшевичким и антифашистичким покретима и појединцима у свету и, нарочито, словенским земљама, а надасве подстицање њиховог организовања (вид. Руколь 1997).

„Словенска” иницијатива, иза које је стајао Президијум ЦК СКП(б) и лично Стаљин, током II светског рата и у првим поратним годинама стекла је доста широку подршку, поготово после успостављања режима народне демократије у словенским земљама које су се све нашле у совјетској сфери утицаја.

У документима и пропаганди из тога времена говорило се о „новом словенском покрету". Синтагму је први употребио Александар Сергејевич Шчербаков, тадашњи главни идеолог ЦК СКП(б), пред крај рата, залажући се за сазивање свесловенског конгреса у Москви:

Славянские народы сыграли огромную роль в этой войне. Война подходит к концу. Фашистская Германия в ближайшие месяцы будет разбита. Надо подумать о новом славянском gвижении [...] в послевоенный период и все эти вопросы практики, теории и истории перенести на обсуждение славянского съезда (Досталь 1994: 129; исто у Досталь 1997: 183).

При томе се циљеви тог новог словенског покрета нису нарочито крили: хегемонија Совјетског Савеза у словенском свету, односно „комунизација" и „совјетизација" словенских држава народне демократије, као и примена - од пропаганде до политичке, друштвене и научне праксе - „једино истинитог учења Маркса-Енгелса-Лењина-Стаљина” (уп. Досталь 1994: 132).

У свим словенским земљама, али и једном броју несловенских, организовани су тако национални словенски комитети. Исто је било и

\footnotetext{
${ }^{1}$ Слични митинзи и радиомитинсзи одржавани су потом 1943, 1943. и 1944 (вид: Досталь 1994: 129).
} 
с Југославијом: према директивама „одозго” основан је још пре ослобођења земље Словенски комитет Југославије - 14. јануара 1945. На челу му је спочетка био Јеврем Недељковић, а касније је на његово место дошао Стеван Јаковљевић, у то време постављени ректор Београдског универзитета, док је функцију генералног секретара обављао Радован Лалић. Овај комитет, по угледу на совјетски, имао је карактер пропаган-

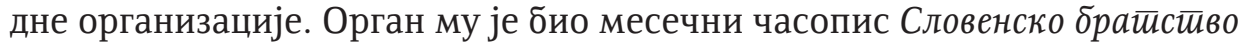
(1947-1949), а у духу своје основне намене објавио је, примера ради, две фото-монографије с упоредним текстом на српском и руском језику: Ослобо оилачка борба нароgа Јуі̄ославије ирооиив фашистичикої завоје-

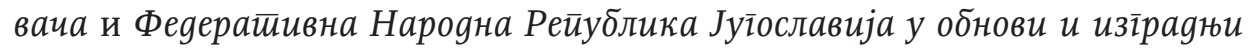
(обе 1946).

На тај је начин, дакле, и Југославија укључена у „нови словенски покрет", а у њему су, силом прилика, учествовали наши интелектуалци, па и слависти од великог угледа.

Узгред, не треба губити из вида да је „нови словенски покрет” - осим (неповољног) утицаја на научну славистику као тематску грану хуманистике - имао више него значајне геополитичке реперкусије. Стаљинови утопистички пројекти стварања пољско-чехословачке и балканске (тј. југословенско-бугарске, потом југословенско-бугарскоалбанске) федерације у зору хладног рата, и то, разуме се, уз лидерску улогу Совјетског Савеза (вид. Đilas 1986: 100), једно су од лица и претпостављених крајњих домета ове доктрине.

\section{2. Први свесловенски конгрес у Београду 1946.}

Као што је већ споменуто, Шчербаков је изнео идеју сазивања свесловенског конгреса још 1944. године. Већ почетком 1945. Словенски комитет Бугарске предложио је да се конгрес одржи у Софији, али ова иницијатива није подржана због ангажовања Бугарске у II светском рату на страни Хитлерове Немачке. Ипак, одлучено је да се у Софији организује манифестативни митинг и саветовање, тзв. Словенски сабор (одржан почетком марта 1945).

У лето 1945. у Москви је, на прослави 220. годишњице Академије наука СССР, боравила делегација САНУ коју су чинили председник САНУ Александар Белић и академици Синиша Станковић и Јеврем Недељковић (тада председник Словенског комитета Југославије) и том приликом званично поднели кандидатуру Београда за одржавање свесловенског конгреса 1946. Иницијатива је наишла на свеопшту подршку, па је већ септембра 1945. у Београду одржан припремни састанак и сазван Припремни комитет (уп. Досталь 1994: 130). 
У јулу 1946. утврђена је тематика конгреса и термин његовог одржавања - 8. децембра 1946. Припреме су текле под строгим идеолошким надзором у свим словенским комитетима, а главну реч водио је, разумљиво, „центар”. Одређена су три основна питања, као и главни референти: 1) словенски народи у борби за мир (министар без портфеља у влади ФНРЈ - Милован Ђилас); 2) допринос словенских народа светској култури (академик Борис Дмитријевич Греков); 3) организациона питања, тачније „нови словенски покрет и задаци словенских организација" (генерал-лајтнант Александар Семјонович Гундоров, председник Свесловенског комитета и уједно главни извршни ауторитет у читавом том „новом словенском покрету”).

Конгрес је одржан од 8. до 11. децембра 1946. у Београду и протекао је сасвим у складу са тврдо задатим смерницама, па и циљевима совјетске делегације (уп. Досталь 1994: 130).

О самом току конгреса, учесницима, изнетим идејама и ставовима детаљно су писали Марија Јурјевна Достаљ (Досталь 1994) и Момчило Митровић (Mitrobić 1999), а ми ћемо споменути нешто занимљивости и оно што је битно за нашу тему.

Према новинским извештајима, конгрес је отворен свечано, чак помпезно, потпуно у складу с правилима сценографије и протокола комунистичких окупљања од посебног значаја. Велику салу Коларчевог народног универзитета красили су, примера ради, огромни портрети Јосифа Стаљина, Јосипа Броза, Болеслава Бјерута, Едварда Бенеша и Георгија Димитрова. Његов рад пратиле су масовне манифестације „спонтане” подршке. На отварању је, словенски надахнуто, уз овације присутних говорио Јосип Броз као председник Владе ФНРЈ, а били су присутни председник Скупштине Иван Рибар, министри и други званичници. Прочитани су поздравни телеграми „највећег пријатеља словенских народа" - Стаљина, затим словенских лидера Бјерута, Бенеша, Димитрова...

У оквиру друге теме конгреса, о доприносу словенских народа светској култури, говорио је и Александар Белић као један од Грековљевих кореферената. Као куриозитет навешћемо главну идеологему ове теме, коју је формулисао економиста Александар Алексејевич Вознесенски, тадашњи ректор Лењинградског универзитета:

Славянская культура, являясь национальной по форме, в то же время является глубоко народной, гуманистической и общечеловеческой по содержанию. Вершиной развития этих ее особенностей и самым крупным вкладом славян в мировую культуру явилось учение Ленина-Сталина, вскрывшее законы развития человеческого общества в современных условиях, давшее народам самим творить свою историю и открывшее 
путь к счастливому процветанию всего человечества (цит. према Досталь 1994: 136-137).

У уводном реферату о трећој теми Гундоров је дао пречишћену званичну дефиницију „новог словенског покрета”:

...в основу нового славянского движения, не имеющего ничего общего ни с русским царским панславизмом, ни с польским, чешским, сербским и болгарским великодержавным шовинистическим стремлением, легли демократическая платформа боевого единства славянских народов, сложившегося в совместной борьбе со всеми свободолюбивыми народами... Новое славянское движение росло и развивалось как антифашистское и демократическое движение, [направленное против] реакционных клик славянских стран (Досталь 1997: 183).

На конгресу је, у духу организационог уобличавања новог словенског покрета - више ради координације рада националних комитета неголи стварног руковођења покретом - основан Свесловенски комитет са седиштем у Београду, на челу с Божидаром Масларићем. На тај начин престао је да постоји Свесловенски комитет основан 1941. у Москви: преименован је у Словенски комитет СССР, и даље предвођен Гундоровом. Није тешко, међутим, претпоставити да је главну реч и даље водио „центар".

M. Достаљ наводи рукопис Гундоровљевог извештаја о конгресу, намењен по свој прилици новом утицајном идеологу у апарату ЦК СКП(б) Михаилу Андрејевичу Суслову, где се, поред осталог, каже:

Конгресс и особенно поездка по стране, где мы видели сотни тысяч людей, показали, что все: рабочие, крестьяне, интеллигенция отлично понимают, что их независимость, демократические завоевания и все будущее зависят от дружбы с Советским Союзом. Отсюда исходит такая любовь к советскому народу и т. Сталину. Просто обидно, что наш народ недостаточно знает об этом. Все участники съезда стали заяgльми слависииами (курзив - П.Б.) (Досталь 1994: 139-140).

Засад само скрећемо пажњу на овај више него оригинални израз - „загрижени слависти" - који се и те како тиче наше теме.

Од резолуција донетих на београдском конгресу за нас је свакако најзначајнија она о хитном организовању науиноі коніреса славистиа.

\section{3. Неодржани научни конгрес слависта у Москви 1948.}

Овој теми М. Достаљ посветила је прилично исцрпан рад (Досталь 1997) у којем су, корак по корак, документоване припреме совјетских 
политичких и научних структура за предстојећи конгрес. Конгрес је, према резолуцији београдског, требало да се одржи крајем 1947. године. Током припрема у Словенском комитету СССР под будним оком идеолошког апарата ЦК СКП(б) термин се одлагао више пута, да би се напокон од идеје сасвим одустало. Првобитно планиран у октобру/новембру 1947 , одложен је најпре за 15. април 1948, а затим за 18. јуни 1948, да би почетком јуна био одложен још једном - за јесен исте године...

Организатори конгреса били су Општесловенски комитет са седиштем у Београду, Академија наука СССР и њен новоосновани Институт за славистику (Институт славяноведения). Из Општесловенског комитета дириговало се припремама националних комитета, а све време се тематиком и организацијом конгреса заправо бавила врхушка ЦК СКП(б). Занимљиво је да се у припрему конгреса у једном тренутку врло активно умешао чак и идеолог најтвђе линије Андреј Александрович Жданов (вид. Досталь 1997; 2001).

Још током припрема београдског конгреса истицала се (В. В. Мочалов) „слаба марксистичка спрема кадрова, руководилаца словенског покрета" која их води на „лажан и опасан пут” „културњаштва, академизма" (культурничество, академизм) (уп. Досталь 1994: 132). У већ цитираном извештају с београдског конгреса Гундоров запажа:

Не были затронуты критикой существующие течения в области культуры, оставшиеся от довоенного строя в славянских странах. Если у нас сохраняются Зощенки и Ахматовы, то что же делается там, в этих странах, только что переживших революцию (Досталь 1994: 140).

Шта ли се онда могло очекивати у погледу „научног” свесловенског конгреса?! Из сачуваног стенограма саветовања које је ради припрема конгреса организовао Словенски комитет СССР може се сазнати много тога. Посебно је индикативан став који је 5. априла 1947. на том саветовању изнео већ спомињани економиста А. А. Вознесенски, потпредседник Општесловенског комитета:

Мы хотим устроить встречу ученых славянских и может быть неславянских стран не просто ради узкоакадемического интереса... мы хотели бы - это естественно - оказать наше идейное влияние на ученых других стран. Наша идеология и методика... являются [самой] передовой... Такое идейное влияние, если мы его сможем оказать, будет иметь последствия более значительного порядка (Досталь 1997: 185).

Позиција с које се целом послу приступало није се, дакле, скривала: Совјетски Савез, као лидер света народне демократије и ослободилац читавог Словенства, поставља правила и профил будућег конгреса. Тако 
је, на предлог Вознесенског, сачињена структура секција и њихова хијерархија по важности: 1) филозофска, 2) историјска, 3) економска, 4) филолошка, 5) правна, 6) географска и геолошка (?!), 7) етнографска (вид. Досталь 1997: 186).

О организационим питањима одлучивало се на трима пленумима Општесловенског комитета - у Варшави (15-18. јуна 1947), Софији (11. октобра 1947) и Прагу (25-26. фебруара 1948).

Изненадно одлагање практично већ сазваног и организованог конгреса 4. јуна 1948. године заправо је почетак краја читавог пројекта „новог словенског покрета”, изазваног затезањем односа комунистичких партија окупљених око СКП(б) са КПЈ. Резолуција Информбироа и политичка конфронтација на релацији Москва-Београд ставиле су крст на словенску политику Совјетског Савеза. Отказан је и свесловенски конгрес у Прагу, планиран на стогодишњицу одржавања првога 1848. Совјетски идеолози убрзо су се поново вратили концепту пролетерског интернационализма, а словенски комитети у земљама-сателитима гасили су се један за другим. Свесловенски комитет на челу с Масларићем престао је с радом одмах 1948, Словенски комитет Југославије укинут је 1949. Занимљиво је да један број књига у раним аквизицијама библиотеке београдске славистике носи његов печат...

\section{4. Оснивање Славистичког друштва Србије}

О околностима организовања московског конгреса морао је бити подробно обавештен оснивач и први председник Славистичког друштва Србије Александар Белић, велики ауторитет у светској славистици пре II светског рата и главни организатор неодржаног III међународног конгреса слависта у Београду 1939. Такође му је морало бити јасно да се у визури „једино правилног учења” његова концепција славистике као словенске филологије неповратно маргинализује и отворено разграђује. То се, уосталом, види из веома документованог рада Богољуба Станковића „Александар Белић у славистичком покрету” (Станковић 2007: 38), где се, додуше, Белићево ангажовање у „новом словенском покрету” посебно не експлицира, али где се детаљно анализирају његови погледи на славистику пре и после II светског рата, нарочито у вези с београдским састанком слависта 1955. и обнављањем међународног славистичког покрета какав данас познајемо.

Белић је у пролеће 1948. подржао иницијативу чланова Катедре за источне и западне словенске језике и књижевности Филозофског факултета у Београду да се оснује друштво за неговање и ширење научно заснованих знања о словенским језицима и књижевностима. Та је ини- 
цијатива довела до одржавања оснивачке скупштине Друштва 29. јуна 1948, на којој је, у име Иницијативног одбора, Белић поднео реферат о задацима славистике. Скупштина га је потом изабрала за првог председника Друштва, што је остао до саме своје смрти 1960. године. ${ }^{2}$

Да ли је, дакле, Славистичко друштво Србије основано непосредно на таласу „новог словенског покрета”? Одговор је, биће, негативан. И поред изнуђеног ангажовања српских слависта различитих профила било у телима Словенског комитета Југославије, било као сарадника Словен-

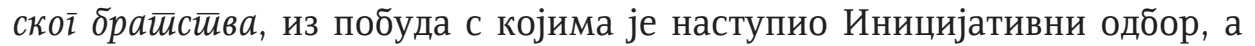
посебно из плана рада за 1949. годину (вид. Станковић 2008: 18, 20-21) јасно се види да је профил Друштва у основи - филолошки. Ни трага политичкој економији, праву или географији, а камоли геологији... Тематика првих реферата на научним седницама можда се није косила с владајућом идеологијом, већ јој је, напротив, у нечему повлађивала, али је поштовала добре традиције српске и светске славистике.

А да ли му је сврха била организовање учешћа на московском конгресу? Наравно да не. Прво, томе противуречи хронологија: зашто оснивати друштво неколико недеља после фактичког отказивања конгреса? Друго, Друштво је деловало на територији НР Србије, а не целе ФНРЈ. И најзад треће, тело које је заступало слависте из ФНРЈ, тиме и Србије, у пословима око организације конгреса био је - Словенски комитет Југославије. Оснивање Славистичког друштва Србије било је, дакле, ауйениичнна науина иницијаииива.

Надам се да сам бар донекле успео у намери да скинем етикету „стаљинизма” с првих деценија рада Славистичког друштва - ако не у погледу метода рада, јер диктирало их је време, оно бар у погледу научног интегритета и часног позиционирања струке у више него деликатним околностима.

Тема овога прилога могла је гласити и, рецимо, „Славистичко друштво пре седам деценија: између славистике и параславистике”. При томе под ad hoc термином „параславистика” подразумевам свеукупност идеолошки и геополитички мотивисаних, научно безвредних, теоријски и практично неодрживих, а пропагандистички и популистички усмерених теза и ставова који претендују да себи потчине научну славистику. Вредност чињенице самога оснивања нашег друштва управо онда, пре седам деценија, и његовог трајања до данас лежи у томе што је аутори-

${ }^{2}$ О самом чину оснивања, потписницима оснивачког акта и активностима Славистичког друштва Србије у првим годинама постојања вид. Станковић 2008. 
тетом и умешношћу како оснивача, тако и већине оних који су друштво водили током деценија, а упркос повременим притисцима, па и отвореним покушајима, Славистичко друштво Србије било и остало имуно на контаминацију „параславистиком”. Можемо бити поносни што су међу нама деловали и делују убеђени, али не и заірижени слависти, попут оних о којима је говорио Гундоров у свом тајном извештају из 1946.

Међутим, опасност од посрнућа у „параславистику” и метанауку ни издалека није прошла. И данас постоје јаке тенденције да се Словенима иманентан осећај блискости и солидарности претвори у чврст покрет - на традицијама оног борбеног „новог словенског” из II светског рата и опет с провидним империјалним амбицијама. Уосталом, у јесен 2017. године, што је може бити промакло пажњи славистичке јавности, одржан је у Београду Други свесловенски конгрес - као омаж ономе из 1946.

\section{Цитирана литература}

Буњак, Петар. „50. скуп слависта у знаку сећања на Богољуба Станковића”. Славистика, ХЫ, 2012.

Досталь Марина Юрьевна. «Славянский конгресс в Белграде в 1946 г.» [В:] Досталь М. Ю и др. (ред.). Славянские съезды ХІХ-XX вв. Москва: РАН, 1994, 128-142.

Досталь, М. Ю. «Идея славянской солидарности и несостоявшийся в Москве в 1948 г. первый общеславянский конгресс ученых славистов». [В:] Досталь М. Ю. и др. (ред.). Славянский вопрос: вехи истории. Москва: РАН, 1997, 182-203.

Досталь М. Ю. «Запись беседы А.А. Жданова с организаторами конгресса ученыХ-славистов. Март 1948 г.». Исторический архив, 5, 2001.

Руколь, Бася Менделевна. «Идея общности славян в материалах Всеславянского комитета в Москве». [В:] Досталь М. Ю и др. (ред.). Славянский вопрос: вехи истории. Москва: РАН, 1997, 204-210.

Станковић, Богољуб. „Александар Белић у славистичком покрету”. Јужнословенски филолог, LXIII, 2007.

Станковић, Богољуб. 60 година Славистичког друштва Србије. Београд: Славистичко друштво Србије, 2008.

Đilas, Miloьan. Susreti sa Staljinom. London: Naša reč, 1986.

Mitrobić, Momčilo. „Prьi posleratni sьesloьenski kongres 1946. godine”. Токоьi istorije, 1-4, 1999, 118-127. 


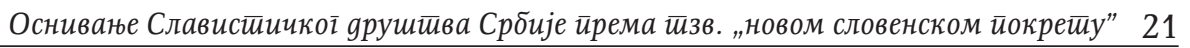

Петр Буняк

\author{
СОЗДАНИЕ ОБЩЕСТВА СЛАВИСТОВ СЕРБИИ И Т. НАЗ. \\ «НОВОЕ СЛАВЯНСКОЕ ДВИЖЕНИЕ»
}

\begin{abstract}
Резюме
В докладе рассматривается ряд фактов политической и общественной истории, связанных с т. наз. «новым славянским движением», как идеологическим оружием ВКП(б) в борьбе с фашизмом, которые предшествовали созданию Общества славистов Сербии 29 июня 1948 г. Автор старается ответить на вопрос, состоит ли факт основания Общества в прямой связи с вынужденным участием ряда сербских славистов в мероприятиях «нового славянского движения». Сопоставляя две модели славяноведения - «нового славянского движения» и легшей в основу Общества славистов - автор приходит к выводу, что Общество с самого начала опирается на традиции славяноведения, как (преимущественно) славянской филологии. Оспаривается также мнение, что целью создания Общества было участие серббских славистов в несостоявшемся московском съезде ученыХ-славистов в 1948 г. В этой связи противопоставляется собственно славистика/славяноведение в академическом понимании - «параславистике», как ненаучному, пропагандистскому и демагогическому проявлению славянской солидарности.

Ключевые слова: «новое славянское движение», идеология коммунизма, славистика/славяноведение, «параславистика», Общество славистов Сербии
\end{abstract}

